\title{
The Study on Navel Orange Traceability Chain
}

\author{
Huoguo Zheng ${ }^{1,2}$, Xianxue Meng ${ }^{1,2}$, and Shihong Liu ${ }^{1,2}$ \\ ${ }^{1}$ Key Laboratory of Digital Agricultural Early-warning Technology Ministry of Agriculture, \\ People's Republic of China, Beijing 100081, P.R. China \\ ${ }^{2}$ Agricultural Information Institute of Chinese Academy of Agriculture Science, \\ Beijing 100081, P.R. China
}

\begin{abstract}
Navel orange is one of the characteristic agricultural products in the middle region of china. The traceability system for navel orange can enhance consumer confidence due to the "stained navel orange" incident. Research on the navel orange traceability chain is the foundation and premise of building the traceability system. Based on the analyses of whole food chain of navel orange from origin to market, HACCP is used to evaluate the risk and latent risk of planting, harvesting, processing, packing, transportation and sale, the critical control link and the critical control point of navel orange traceability chain were fixed combined with the actual situation in china. Further, the code of the navel orange traceability is designed based on EAN.UCC system, which includes origin, processing and the end product. This study makes it possible to construct navel orange traceability system.
\end{abstract}

Keywords: navel orange, critical control point, HACCP, traceability chain, encode.

\section{Introduction}

Navel orange is one of characteristic agricultural products in the middle of china, which is demanding climate for growing. The origin of the navel oranges mainly distributed in south Jiangxi province, zigui, Hubei province, fengjie, Chongqing province, binzhou, Yunnan province.

Gannan is located in the sub-tropical southern margin of the South. The climate of gannan is a typical sub-tropical moist climate, the soil of gannan contains many kinds of trace elements for fruit tree and navel orange, both of them suit navel oranges grow.

Gannan is the advantageous product area of navel orange determined by ministry of Agriculture in China. Gannan is the famous base for navel orange, where is known as "town of navel orange in China". The navel orange produced in gannan has many unique features, such as large shaped, bright color, crisp flesh and taste good. Navel orange industry is an important pillar industry in Gannan region, which is one of nine advantages of agricultural products selected by ministry of agriculture in china. Many counties have taken navel orange as an important tool for local farmer income.

However, the incidents occurred in recently years, such as "dyeing navel orange" in Hong Kong in 2004, "bactrocera minax" in guangyuan city, Sichuan province, have damaged the orange industry in south of china. The "dyeing navel orange" incident made $70 \%$ order in Hong Kong cancellation, the price of navel orange fell sharply in 2004. In 
2008, affected by the "bactrocera minax" incident, all of the consumers don't want to buy navel orange in china. These events cause severe economic losses to fruit growers.

Generally, from tree planting to bear fruit need 2-3 years for navel orange tree, from blooming to outcome need 280-300 days for navel orange. There are a lot of links and elements affect the quality safety for navel orange. In order to standardize the navel oranges grow and process, "Technological regulation of navel orange cultivation in south Jiangxi, south Hunan, and north Guangxi" has been developed to standardize the whole process from tree planting to fruit picking of navel orange.

In order to guarantee the quality safety of navel orange, we should monitor the whole process from tree planting to fruit processing[1], which also called "management from orchard to table". Currently, traceability systems for agricultural products are established gradually to ensure the quality safety[2,3]. As for navel orange, confirm the critical control point based on the analysis of the whole process from tree planting to fruit processing with the HACCP (Hazard Analysis and Critical Control Point)[4], and encode the traceability chain of navel orange with EAN.UCC system, both of them are precondition of traceability system construction.

\section{Main Hazard of Navel Orange}

Generally, there are three kinds of hazard to person in fresh agricultural products: biological hazards, chemical hazards and physical hazards.

The biological hazards of navel orange mainly refer to the biological itself and its metabolites will pollute fruit raw materials, process and products. This pollution will damage consumer safety. As for fruit, hazard generated creatures are fungi, bacteria, viruses, natural toxins, parasites. Specifically, ulcers are the most occurred bacterial diseases for navel orange, which damage a lot to navel orange.

The chemical hazards of navel orange mainly refer to chemical substances, residues and emissions generated by human activities, which contaminated the fruit. Chemical hazards involves a broader range, including environmental pollution, pesticide residues fertilizer residues, chemical element pollution, packaging materials, such pollution damages the health of consumers. For navel orange, atmospheric pollutants are same with other fruits, including total suspended particulates, sulfur dioxide, nitrogen dioxide, and fluoride. Soil contaminants in navel orange include heavy metals, toxic substances (pesticides, various chemicals) and other pollutants. Soil pollution comes mainly from three aspects: First, the discharge of industrial waste; second pesticide, fertilizer application, etc.; third of sewage irrigation.

Physical hazards of navel orange exist in fruit with potentially harm may cause bodily injury to consumers., which are common glass, wire, nails fragments, stones fragments, metal fragments and so on.

\section{Navel Orange Critical Control Point Analysis}

\subsection{Navel Orange Production Process Analysis}

Generally, there are 11 steps from navel orange tree planting to navel orange fruit sold on market: orchard selection, sapling selection, planting, tree management, soil fertilizer and water management, flower and fruit management, insect control, harvest, washing and packing, storage and transportation [5] (shown as Fig. 1). 
When an orchard was selected, we should investigate land use history, soil type, soil erosion and ground water quality. Evaluate whether the regional air, soil, irrigation water and other conditions suit for navel orange growing. During the soil fertilizer and water management period, we should determine the rate, time and method of irrigation and fertilizing. In the insect control stage, different measures should be taken to deal with different diseases, pests.

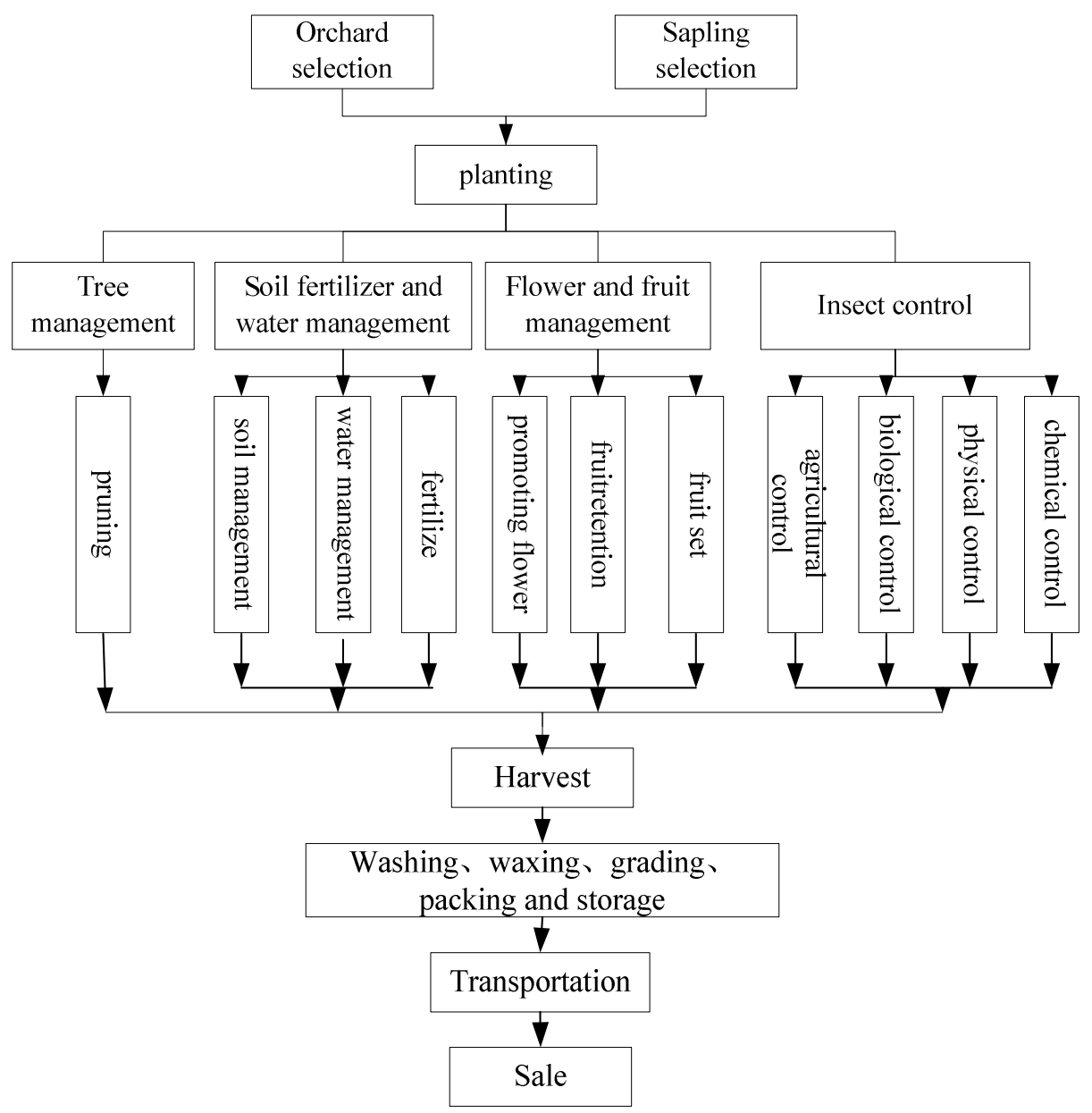

Fig. 1. 11 steps of navel orange growing

\subsection{Navel Orange Safety Factor Analysis}

As we known, navel orange can be sold on market after 11 steps. Among all of these process, potential hazard factors include: environmental conditions, water quality, pesticide residues, etc, which we should analyses detailed from biological hazards, chemical hazards and physical hazards three aspects, then identify the significant hazards[6]. 
There are many links that make navel orange infected bacteria from orchard to sale, but these hazards can generally be controlled by SSOP (Sanitation Standard Operating Procedure). So the biological hazards in navel orange significant hazard.

Chemical hazards that can impact navel orange safety mainly in the following five areas: first, pesticide residues as well as mercury, cadmium, lead, tin, chromium, arsenic, fluoride and other harmful substances residues in soil; second, fluoride and sulfide in air; third, pesticide residues and mercury, cadmium, lead, tin, chromium, arsenic, fluoride residues in irrigation water, fourth, mercury, cadmium, lead, tin, chromium, arsenic, fluorine, and antibiotics residues in fertilizer; fifth, pesticides and heavy metals exceeded in the fruit during the pest control process.

There is no physical hazard to customers in navel orange basically.

\subsection{Critical Control Point of Navel Orange}

Based on the whole process of navel orange and information of hazard analysis, five critical control points was determined (shown in Table 1):

(1) Surroundings, soil properties, pesticide residues and harmful substances in the orchard.

(2) Irrigation water.

(3) Fertilizer selection.

(4) Pesticides in the pest control.

(5) Disinfectant and wax during the washing, waxing, grading and packing.

Table 1. HACCP based Hazard analysis of navel orange

\begin{tabular}{|c|c|c|c|c|c|}
\hline $\begin{array}{l}\text { Production } \\
\text { process }\end{array}$ & Hazard type & $\begin{array}{c}\text { Is } \\
\text { significant? }\end{array}$ & $\begin{array}{c}\text { Judgments based on the } \\
\text { third column }\end{array}$ & Precaution & $\begin{array}{c}\text { Is } \\
\text { CCP? }\end{array}$ \\
\hline \multirow{3}{*}{$\begin{array}{l}\text { Orchard } \\
\text { selection }\end{array}$} & biological hazard & No & & & No \\
\hline & chemical hazard & Yes & $\begin{array}{c}\text { harmful substances and } \\
\text { heavy metals absorption } \\
\text { from the air and water } \\
\text { during navel orange } \\
\text { growing }\end{array}$ & $\begin{array}{c}\text { test the soil, air } \\
\text { and water, } \\
\text { make sure all of } \\
\text { them line with } \\
\text { national } \\
\text { standards } \\
\end{array}$ & Yes \\
\hline & physical hazard & No & & & No \\
\hline \multirow{3}{*}{$\begin{array}{l}\text { Sapling } \\
\text { selection }\end{array}$} & biological hazard & No & & & No \\
\hline & chemical hazard & No & & & No \\
\hline & physical hazard & No & & & No \\
\hline \multirow{3}{*}{ Planting } & biological hazard & No & & & No \\
\hline & \begin{tabular}{|l|} 
chemical hazard \\
\end{tabular} & No & & & No \\
\hline & physical hazard & No & & & No \\
\hline \multirow{3}{*}{$\begin{array}{c}\text { Navel orange } \\
\text { tree } \\
\text { management }\end{array}$} & biological hazard & No & & & No \\
\hline & chemical hazard & Yes & Use growth regulator & limited & No \\
\hline & physical hazard & No & & & No \\
\hline \multirow{3}{*}{$\begin{array}{c}\text { Soil } \\
\text { management }\end{array}$} & biological hazard & No & & & No \\
\hline & chemical hazard & Yes & $\begin{array}{c}\text { Use steamed soil } \\
\text { fumigant }\end{array}$ & limited & No \\
\hline & physical hazard & No & & & No \\
\hline
\end{tabular}


Table 1. (Continued)

\begin{tabular}{|c|c|c|c|c|c|}
\hline \multirow{3}{*}{$\begin{array}{c}\text { Irrigation } \\
\text { management }\end{array}$} & biological hazard & No & & & No \\
\hline & chemical hazard & Yes & $\begin{array}{l}\text { Irrigation water contain } \\
\text { harmful substances, } \\
\text { heavy metals }\end{array}$ & \begin{tabular}{|c|} 
make sure \\
water line with \\
national \\
standards \\
\end{tabular} & Yes \\
\hline & physical hazard & No & & & No \\
\hline \multirow{3}{*}{$\begin{array}{c}\text { Fertilize } \\
\text { management }\end{array}$} & biological hazard & Yes & fertilizer storage & $\begin{array}{l}\text { separate the } \\
\text { fertilizer and } \\
\text { fruit }\end{array}$ & No \\
\hline & chemical hazard & Yes & $\begin{array}{c}\text { Fertilizer contain } \\
\text { harmful substances, } \\
\text { chemical and heavy } \\
\text { metals }\end{array}$ & $\begin{array}{c}\text { Handle the } \\
\text { organic } \\
\text { fertilizer before } \\
\text { use }\end{array}$ & Yes \\
\hline & physical hazard & No & & & No \\
\hline \multirow{3}{*}{$\begin{array}{c}\text { Flower } \\
\text { management }\end{array}$} & biological hazard & No & & & No \\
\hline & chemical hazard & Yes & $\begin{array}{c}\text { Use fruit growth } \\
\text { regulator }\end{array}$ & limited & No \\
\hline & physical hazard & No & & & No \\
\hline \multirow{3}{*}{ Pest control } & biological hazard & Yes & Use biological pesticide & $\begin{array}{l}\text { line with } \\
\text { national } \\
\text { standards }\end{array}$ & No \\
\hline & chemical hazard & Yes & Use chemical pesticide & $\begin{array}{l}\text { line with } \\
\text { national } \\
\text { standards }\end{array}$ & Yes \\
\hline & physical hazard & No & & & No \\
\hline \multirow{3}{*}{ Harvest } & biological hazard & No & & & No \\
\hline & \begin{tabular}{|l|} 
chemical hazard \\
\end{tabular} & Yes & & & No \\
\hline & physical hazard & No & & & No \\
\hline \multirow{3}{*}{$\begin{array}{l}\text { Washing, wax } \\
\text { ing, grading、 } \\
\text { packing }\end{array}$} & biological hazard & No & & & No \\
\hline & chemical hazard & Yes & $\begin{array}{l}\text { Use disinfectant and } \\
\text { wax }\end{array}$ & $\begin{array}{c}\text { make sure all of } \\
\text { them line with } \\
\text { national } \\
\text { standards }\end{array}$ & Yes \\
\hline & physical hazard & No & & & No \\
\hline \multirow{3}{*}{ Storage } & biological hazard & Yes & $\begin{array}{l}\text { Fruit rot during the } \\
\text { storage }\end{array}$ & $\begin{array}{l}\text { Control the } \\
\text { storage } \\
\text { condition }\end{array}$ & No \\
\hline & chemical hazard & Yes & $\begin{array}{c}\text { Use chemical } \\
\text { anti-stalling agents }\end{array}$ & limited & No \\
\hline & physical hazard & No & & & No \\
\hline \multirow[t]{3}{*}{ Transportation } & biological hazard & Yes & $\begin{array}{l}\text { Generate pathogens } \\
\text { during transportation }\end{array}$ & \begin{tabular}{|c|} 
control \\
transportation \\
condition
\end{tabular} & No \\
\hline & chemical hazard & No & & & No \\
\hline & physical hazard & No & & & No \\
\hline \multirow{3}{*}{ Sale } & biological hazard & No & & & No \\
\hline & chemical hazard & No & & & No \\
\hline & physical hazard & No & & & No \\
\hline
\end{tabular}




\section{Navel Orange Traceability Code Design}

In order to track and trace the whole safety information of navel orange, the detail information of each step should be identified and recorded[7,8]. Unified encode system is the premise of navel orange traceability, is also the basis of information exchanging and processing. The encoding system should comply with the following principles: uniqueness, stability, commonality, expandability and applicability.

As for navel orange, we need four identification codes to indicate the quality safety information. There are origin code, enterprise code, processing batch code and traceability code. According origin code we can know the exactly place the navel orange produced, surroundings information of the orchard, and input information during the navel orange growing. Origin code is composed of 3 parts: administrative divisions' code of county, village code and unit sequence code. The code structure is shown in Fig. 2.

\section{$\mathrm{X}_{12} \mathrm{X}_{11} \mathrm{X}_{10} \mathrm{X}_{9} \mathrm{X}_{8} \mathrm{X}_{7} \mathrm{X}_{6} \mathrm{X}_{5} \mathrm{X}_{4} \mathrm{X}_{3} \mathrm{X}_{2} \mathrm{X}_{1}$ \\ unit sequence code \\ village code \\ administrative divisions code of county}

Fig. 2. The code structure of origin code for navel orange

By means of enterprise code, which refer the existing enterprise code, we can know where the navel orange washing, waxing, grading and packing.

The information about the disinfectant and wax can be obtained by means of processing batch code, which has two parts, processing date and sequence code. Processing batch code structure is shown in Fig. 3.

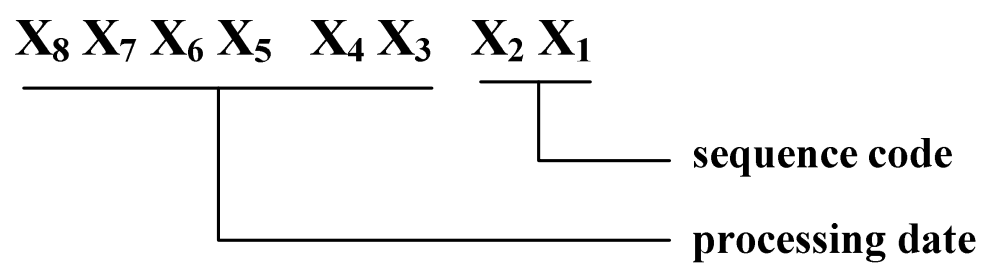

Fig. 3. The code structure of processing batch

The traceability code is the unique identification of navel orange. All of the quality and safety information of the product can be obtained through this code, combined with the navel orange traceability system. The traceability code follows the UCC/EAN-128 standard [9], which is a worldwide standard for exchanging data between different companies. The code structure is shown in Fig. 4. 


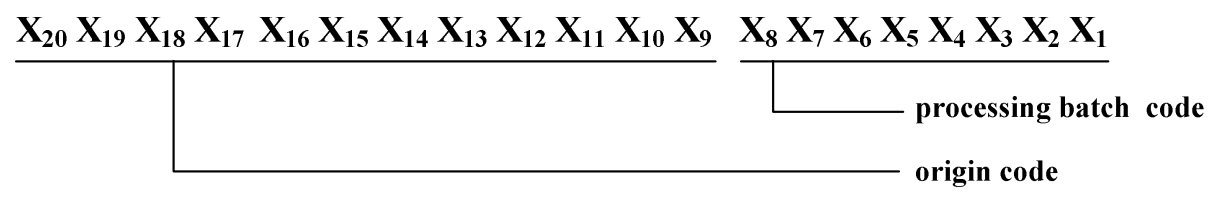

Fig. 4. The code structure of navel orange traceability

\section{Conclusion}

This paper discusses what the traceability system should trace; and which code should encode for implementation of the traceability system of navel orange in the traceability chain. Three main hazards of navel orange are pointed out in the paper; those may harm consumers' health. Based on analyses the whole process from orchard selection to navel orange sale, as well as safety factor of navel orange, five critical control points of navel orange are determined with HACCP method. These critical control points are the focus of the traceability system; and they should be recorded precisely during the entire process. In the end of this article, the author designs the key code of navel orange traceability chain, which includes origin code, processing batch code and traceability code. This study makes the navel orange traceability system construction possible.

Acknowledgements. This study is supported by The National Science and Technology Support Programme (2009BADC4B04).

\section{References}

1. Fan, H., Feng, Z., Yang, L., Ren, A.: Appliance and Discussion of Traceability System in Food Chain. Ecological Economy 17(4), 30-33 (2007)

2. Xing, W.: The Policy of Traceability in Quality and Safety of Agricultural Products in USA. World Agriculture (04) (2006)

3. Opara, L.U.: Traceability in agriculture and food supply chain: A review of basic concepts, technological implications and future prospects. Food, Agriculture \& Environment 1(1), 101-106 (2003)

4. Dayue, B.: Guide to implementation of HACCP. Chemical Industry press (2007)

5. Xu, J.: Agricultural product supply chain-Guarantee food safety. China Logistics \& Purchasing (07) (2005)

6. Yu, H., An, Y.: Theoretical discussion of implementation Traceability System in food supply chain. Agricultural Quality and Standards (03) (2005)

7. Zhang, G., Chen, G.: Food safety and Traceability System. China Logistics \& Purchasing (14) (2005)

8. Zhou, Y., Geng, X.: Application of Traceability in Food Safety. Research of Agricultural Modernization (06) (2002)

9. Yang, X., Sun, C., Qian, J., et al.: Application of UCC/EAN-128 bar code technology in agricultural product safety traceability system. Computer engineering and applications 43(1) (2007) 